\title{
Estrogen receptor specificity in the regulation of the skeleton in female mice
}

\author{
M K Lindberg, S L Alatalo ${ }^{1}$, J M Halleen ${ }^{1}$, S Mohan ${ }^{2}$, \\ J Å Gustafsson ${ }^{3}$ and C Ohlsson
}

Division of Endocrinology, Department of Internal Medicine, Sahlgrenska University Hospital, S-41345 Gothenburg, Sweden
${ }^{1}$ Institute of Biomedicine, Department of Anatomy, University of Turku, FIN-20520, Turku, Finland
${ }^{2}$ Department of Medicine, Loma Linda University, Musculoskeletal Disease Center, Pettis Veterans Administration Medical Center, Loma Linda,
$\quad$ California 92357, USA
${ }^{3}$ Department of Medical Nutrition, Karolinska Institute, Novum, Huddinge, S-14157, Sweden
(Requests for offprints should be addressed to C Ohlsson, Department of Internal Medicine, Division of Endocrinology, RCEM, Sahlgrenska Hospital,
S-41345 Göteborg, Sweden; Email: Claes.Ohlsson@medic.gu.se)

\begin{abstract}
There are two known estrogen receptors, estrogen receptor- $\alpha(E R \alpha)$ and estrogen receptor- $\beta(\operatorname{ER} \beta)$, which may mediate the actions of estrogen. The aim of the present study was to compare fat content, skeletal growth and adult bone metabolism in female mice lacking ER $\alpha$ (ERKO), ER $\beta$ (BERKO) or both ERs (DERKO). We demonstrate that endogenous estrogens decrease the fat content in female mice via ER $\alpha$ and not ER $\beta$. Interestingly, the longitudinal bone growth was decreased in ERKO, increased in BERKO, but was intermediate in DERKO females, demonstrating that ER $\alpha$ and $\operatorname{ER} \beta$ exert opposing effects in the regulation of longitudinal bone growth. The effects on longitudinal bone growth were
\end{abstract}

correlated with similar effects on serum levels of IGF-I. A complex regulation of the trabecular bone mineral density (BMD), probably caused by a disturbed feedback regulation of estrogen and testosterone, was observed in female ER-inactivated mice. Nevertheless, a partial functional redundancy for $\operatorname{ER} \alpha$ and $\operatorname{ER} \beta$ in the maintenance of the trabecular BMD was observed in the female mice at 60 days of age. Thus, ER $\alpha$ and ER $\beta$ may have separate effects (regulation of fat), opposing effects (longitudinal bone growth) or partial redundant effects (trabecular BMD at 60 days of age), depending on which parameter is studied.

Journal of Endocrinology (2001) 171, 229-236

\section{Introduction}

Estrogen is of importance for the regulation of pubertal growth and adult bone metabolism in females. The importance of estrogen in maintaining the trabecular bone mineral density (BMD) in the adult skeletal tissue is clearly illustrated by the pronounced trabecular bone loss observed in estrogen-deficient states, such as in postmenopausal osteoporosis and after ovariectomy. The exact mechanism whereby estrogen exerts its effect in the skeleton remains poorly understood.

There are two known estrogen receptor (ER) subtypes, denoted ER $\alpha$ and ER $\beta$ (Green et al. 1986, Kuiper et al. 1996). The role of these two receptors in mediating the effect of estrogen on bone is not fully understood. However, it has been demonstrated that both ER $\alpha$ and ER $\beta$ are expressed in the growth plate as well as in the bone, suggesting a role for both ER subtypes in the regulation of skeletal homeostasis (Arts et al. 1997, Onoe et al. 1997, Kusec et al. 1998, Lim et al. 1999, Nilsson et al. 1999, Vidal et al. 1999a, Windahl et al. 2000).
We have previously shown that female mice lacking ER $\alpha$ (ERKO) display decreased appendicular growth, while female mice lacking ER $\beta$ (BERKO) display an increased appendicular growth (Vidal et al. 1999b, Windahl et al. 1999), demonstrating an important role for estrogen in the regulation of longitudinal bone growth. The fact that some estrogenic effects are preserved in ERKO mice (Das et al. 1997, Iafrati et al. 1997, Shughrue et al. 1997) and BERKO mice (Karas et al. 1999, Windahl et al. 1999) indicates that alternative pathways may be involved or that possible compensatory activity of the remaining ER subtype may exist, i.e. functional redundancy.

The recent development of Double-Estrogen Receptor Knockout (DERKO) mice makes it possible to functionally distinguish between $\operatorname{ER} \alpha$ and $\operatorname{ER} \beta$ as well as other estrogen dependent pathways in vivo (Couse et al. 1999). In the present study, we investigated the role of ER subtypes in the regulation of skeletal growth and adult bone metabolism in female mice. 


\section{Materials and Methods}

Animals

Male double heterozygous $\left(\mathrm{ER} \alpha^{+/-} \beta^{+/-}\right)$mice were mated with female double heterozygous $\left(\mathrm{ER} \alpha^{+/-} \beta^{+/-}\right)$ mice, resulting in $\mathrm{ER} \alpha^{+/+} \mathrm{ER} \beta^{+/+}$(wild type, WT), $\mathrm{ER} \alpha^{-/-} \mathrm{ER} \beta^{+/+}$(ERKO), $\mathrm{ER} \alpha^{+/+} \mathrm{ER} \beta^{-/-}$(BERKO) and $\mathrm{ER} \alpha^{-1-} \mathrm{ER} \beta^{-/-}$(DERKO) offspring with a mixed C57BL/6J/129 background (Lubahn et al. 1993, Krege et al. 1998). Disruption of the mouse ER $\alpha$ gene was obtained by insertion of a neomycin-resistance gene into exon 2, resulting in a disruption of the reading frame, as previously described (Lubahn et al. 1993). Disruption of the DNA-binding domain of the ER $\beta$ gene was obtained by an insertion of a neomycin-resistance gene into exon 3 of the ER $\beta$ gene as previously described (Krege et al. 1998). The numbers of animals in the first experiment (60 days of age) were WT $n=14$, ERKO $n=8$, BERKO $n=19$ and DERKO $n=15$. In the second experiment (140 days of age) the numbers of animals were WT $n=10$, ERKO $n=9$, BERKO $n=10$ and DERKO $n=10$. Genotyping of tail DNA was performed at 3 weeks of age as previously described (Vidal et al. 2000). Animals had free access to fresh water and food pellets (B\&K Universal AB, Sollentuna, Sweden) consisting of cereal products $(76.9 \%$ barley, wheat feed, wheat and maize germ), vegetable proteins (14.0\% hipro soya) and vegetable oil ( $0 \cdot 8 \%$ soya oil).

\section{Dual-energy X-ray absorptiometry (DXA)}

Measurement of bone mineral content (BMC) and areal bone mineral density (aBMD) was performed with the Norland pDEXA Sabre (Norland, Fort Atkinson, WI, USA) and the Sabre Research software (v3.6) as previously described (Windahl et al. 1999). Briefly, the machine was calibrated daily with a phantom provided by the manufacturer. Medium resolution scans, with line spacing set at $0.05 \mathrm{~cm}$, were used. Three mice were analyzed at a time, including one mouse that was sacrificed at the beginning of the experiment and included in all the scans to avoid inter-scan variation. The inter-assay coefficient of variation was less than 5\% (Andersson et al. 2001). An in vivo prediction of fat content was performed as described previously (Ohlsson et al. 2000).

\section{Peripheral quantitative computerized tomography ( $p$ QCT)}

Computerized tomography was performed with the Stratec pQCT XCT Research M (Norland; v5•4B) operating at a resolution of $70 \mu \mathrm{m}$, as previously described (Windahl et al. 1999).

Cortical parameters were determined with a middiaphyseal pQCT scan of the tibiae. Trabecular BMD was determined with a metaphyseal pQCT scan of the proximal tibiae positioned at a distance from the growth plate corresponding to $1.3 \%$ of the total length of the
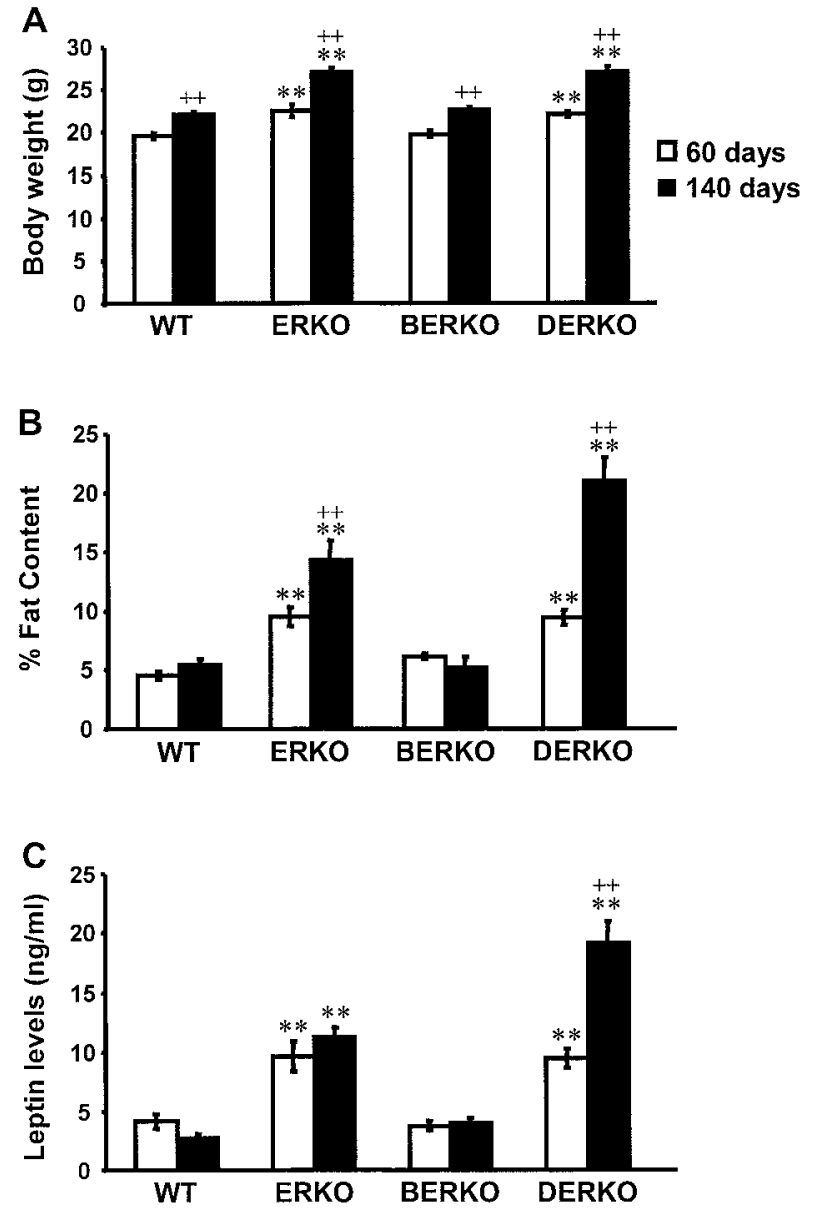

Figure 1 Body weight (A), fat content, as determined using DXA (B), and serum leptin levels (C) in WT, ERKO, BERKO and DERKO females at 60 days of age (open bars) and at 140 days of age (filled bars). Values are given as means \pm S.E.M.s (60 days old: WT $n=14$, ERKO $n=8$, BERKO $n=19$, DERKO $n=15 ; 140$ days old: WT $n=10$, ERKO $n=9$, BERKO $n=10$, DERKO $n=10$ ). Values were first analyzed with one-way ANOVA followed by Student-Newman-Keuls multiple range test. ${ }^{*} P<0 \cdot 01$ versus WT, ${ }^{++} P<0 \cdot 01$ versus 60 days old.

tibiae. The trabecular bone compartment was defined as the inner $45 \%$ of the total area. The inter-assay coefficients of variation $(\mathrm{CV})$ for the $\mathrm{pQCT}$ measurements were less than $2 \%$. We have previously shown that this measurement of trabecular BMD is very well correlated to measurement of the ratio of trabecular bone volume (BV) to total volume (TV) (BV/TV) by histomorphometry (Windahl et al. 2001).

\section{$R I A$}

Serum insulin-like growth factor-I (IGF-I) levels were measured by double antibody IGF binding proteinblocked RIA (Blum \& Breier 1994). Serum osteocalcin 

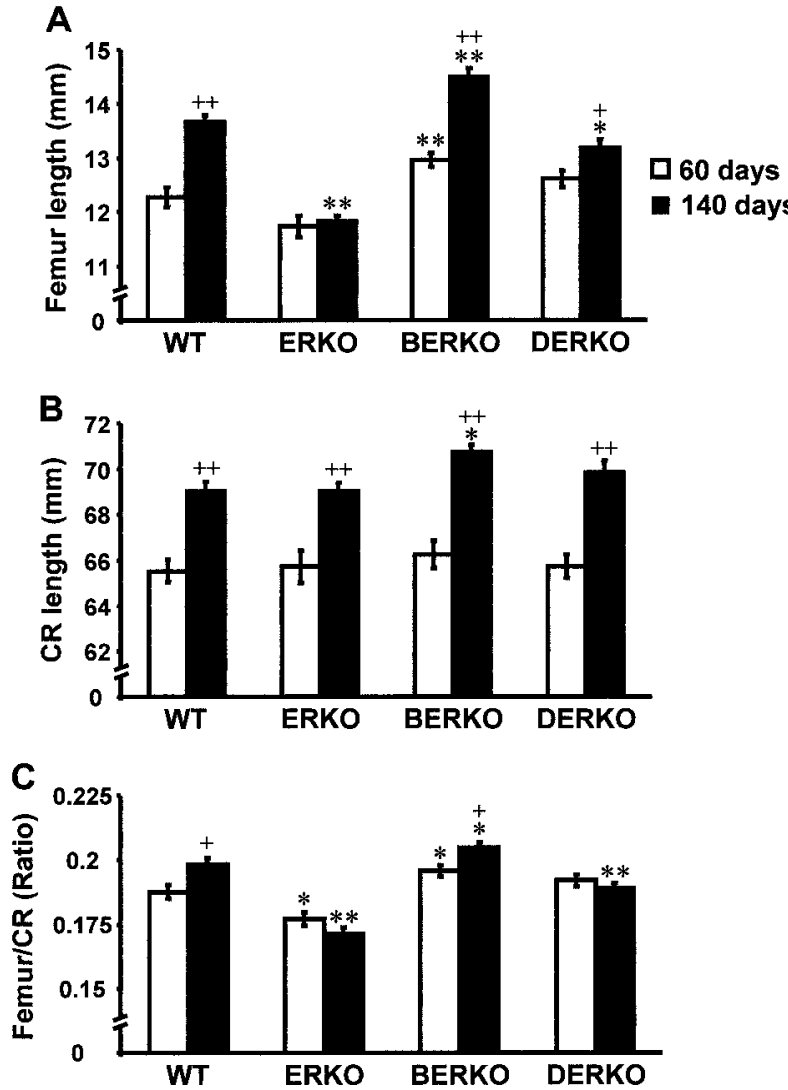

Figure 2 Femur length (A), crown-rump length (CR) (B), and the femur/CR ratio $(C)$ in WT, ERKO, BERKO and DERKO females at 60 days of age (open bars) and at 140 days of age (filled bars). Values are given as means \pm S.E.M.S (60 days old: WT $n=14$, ERKO $n=8$, BERKO $n=19$, DERKO $n=15 ; 140$ days old: WT $n=10$, ERKO $n=9$, BERKO $n=10$, DERKO $n=10$ ). Values were first analyzed with one-way ANOVA followed by Student-NewmanKeuls multiple range test. ${ }^{*} P<0 \cdot 05,{ }^{*} P<0 \cdot 01$ versus WT, ${ }^{+} P<0 \cdot 05$, ${ }^{++} P<0 \cdot 01$ versus 60 days old.

levels were measured by RIA using rabbit anti-mouse osteocalcin antiserum and purified mouse osteocalcin as standard and tracer (Richman et al. 1999). The sensitivity of the mouse osteocalcin assay was $0.5 \mathrm{ng} / \mathrm{ml}$ and intraand inter-assay CVs were less than $8 \% .17 \beta$-estradiol was measured using a RIA detecting estradiol (DiaSorin, Saluggia, Italy), with a sensitivity below $5 \mathrm{pg} / \mathrm{ml}$ at $95 \%$ confidence limit. Testosterone was measured using Immuchem Double Antibody Testosterone RIA, with a sensitivity of $0.1 \mathrm{ng} / \mathrm{ml}$ (ICN Biomedicals Inc., Costa Mesa, CA, USA). Levels of c-telopeptide were measured in serum by an ELISA which measures degradation products of type I collagen that is generated by osteoclastic bone resorption (Srivastava et al. 2000). The sensitivity of the ELISA was less than $0 \cdot 1 \mathrm{ng} / \mathrm{ml}$. The average intra- and inter-assay CVs were less than $12 \%$. Serum leptin levels were measured by an ELISA (Chrystal Chem Inc.,

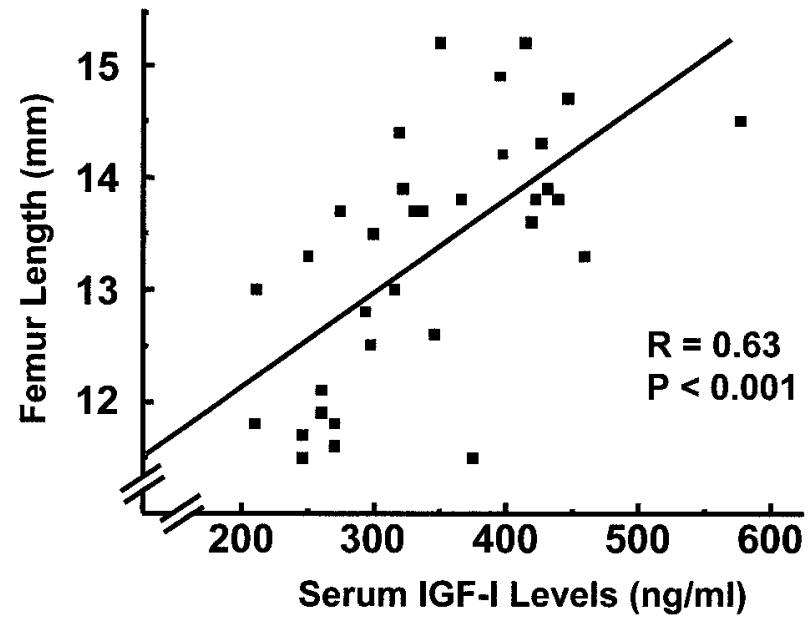

Figure 3 Linear regression analysis of femur length as independent variable and serum IGF-I levels as dependent variable. Femur length and serum IGF-I levels were measured in 140-day-old female WT $(n=10)$, ERKO $(n=9)$, BERKO $(n=10)$ and DERKO $(n=7)$ mice. Pearson's correlation coefficient $(r)$ was calculated. $t$-tests were used and a $P$ value $<0.05$ was considered significant.

Chicago, IL, USA) with an intra-assay and inter-assay CVs of 5.4 and $6.9 \%$ respectively.

Tartrate-resistant acid phosphate (TRAP) 56 immunoassay

TRAP 5b, purified from human osteoclasts as described (Halleen et al. 1996), was used as antigen to develop a polyclonal antiserum in rabbits (Alatalo et al. 2000). The antiserum was incubated on antirabbit IgG-coated microtiter plates (EG \& G Wallac) for $1 \mathrm{~h}$. Diluted mouse serum samples were incubated in the wells for $1 \mathrm{~h}$, and bound enzyme activity was detected using $8 \mathrm{mmol} / 1$ 4-nitrophenyl phosphate (4-NPP) as substrate in $0 \cdot 1 \mathrm{~mol} / 1$ sodium acetate buffer, $\mathrm{pH} 6 \cdot 1$, for $2 \mathrm{~h}$ at $37^{\circ} \mathrm{C}$. The enzyme reactions were terminated by adding $25 \mu$ of $0.32 \mathrm{~mol} / 1 \mathrm{NaOH}$, and $A_{405}$ was measured using model 2 Victor equipment (EG \& G Wallac).

\section{Results}

Body growth

At 60 days of age, shortly after sexual maturation in WT mice, the body weight was increased in female ERKO and DERKO but not in BERKO mice compared with WT mice (Fig. 1A). These effects on body weight were more pronounced at 140 days of age (Fig. 1A). Because of the increase in body weight in ER $\alpha$ inactivated mice, body fat content and serum leptin levels were analyzed. The body fat content, as measured with DXA, was increased in ERKO and DERKO but not in BERKO females 




B



WT

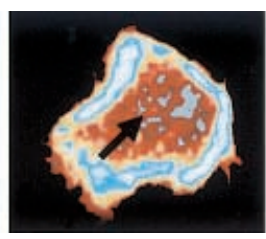

ERKO

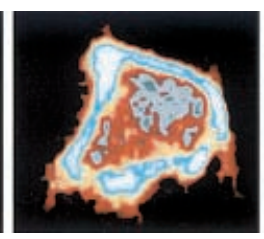

BERKO

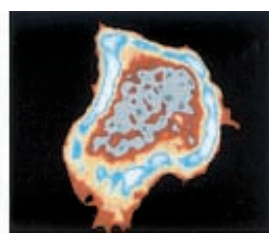

DERKO

Figure 4 Trabecular BMD in WT, ERKO, BERKO and DERKO females at 60 days of age (open bars) and at 140 days of age (filled bars), as measured in a metaphyseal pQCT scan of the proximal tibiae (A). Values are given as means \pm S.E.M.S ( 60 days old: WT $n=14$, ERKO $n=8$, BERKO $n=19$, DERKO $n=15 ; 140$ days old: WT $n=10$, ERKO $n=9$, BERKO $n=10$, DERKO $n=10)$. Values were first analyzed with one-way ANOVA followed by Student-Newman-Keuls multiple range test. ${ }^{*} P<0 \cdot 05,{ }^{*} P<0 \cdot 01$ versus WT, ${ }^{++} P<0 \cdot 01$ versus 60 days old. Representative metaphyseal pQCT scan of the proximal tibiae in female WT, ERKO, BERKO and DERKO mice at 60 days of age (B). The arrow indicates a central area consisting of trabecular bone.

(Fig. 1B). The effects on fat content were associated with similar effects on serum levels of leptin (Fig. 1C).

The femur length was used as a measurement of appendicular growth. At 60 days of age there was an increase in the BERKO (6\%), while no change was seen in the DERKO as compared with WT mice. At 140 days of age the femur length was decreased in ERKO (-14\%) while it was increased in BERKO mice (6\%). A small decrease was seen in 140 days old DERKO (-4\%) mice as compared with WT mice. However, the femur length in female DERKO mice, at 140 days of age, was intermediate between the lengths of ERKO and BERKO mice (Fig. 2A). The crown-rump (CR) length was used as a measurement of the axial skeletal growth. It was unchanged between all genotypes except for a small increase (3\%) in BERKO mice compared with WT at 140 days of age (Fig. 2B). The differential effects on the appendicular and the axial skeletal growth were illustrated by the fact that ERKO mice displayed a decreased femur/CR ratio, while BERKO mice displayed an increased ratio (Fig. 2C). DERKO mice had a femur/CR ratio that was intermediate between ERKO and BERKO mice. An altered length of femur is often associated with a disturbed growth hormone-IGF-I axis. A two-way ANOVA, in which $\mathrm{ER} \alpha^{-/-}$and $\mathrm{ER} \beta^{-/-}$were regarded as separate treatments, demonstrated that serum levels of IGF-I were decreased in $\mathrm{ER} \alpha^{-1-}$ while they were increased in $E R \beta^{-1-}$ mice at 140 days of age (WT, $354 \pm 20 \mathrm{ng} / \mathrm{ml} ; \quad$ ERKO, $277 \pm 15 \mathrm{ng} / \mathrm{ml} ;$ BERKO, $412 \pm 23 \mathrm{ng} / \mathrm{ml} ; \quad$ DERKO, $319 \pm 22 \mathrm{ng} / \mathrm{ml}, \quad P<0 \cdot 05$, two-way ANOVA followed by Student-Newman-Keuls multiple range test). Furthermore, the length of femur was correlated with serum IGF-I levels in ER inactivated mice (Fig. 3). 
Table 2 DXA measurements of aBMD and BMC. Values are given as \% WT \pm S.E.M.

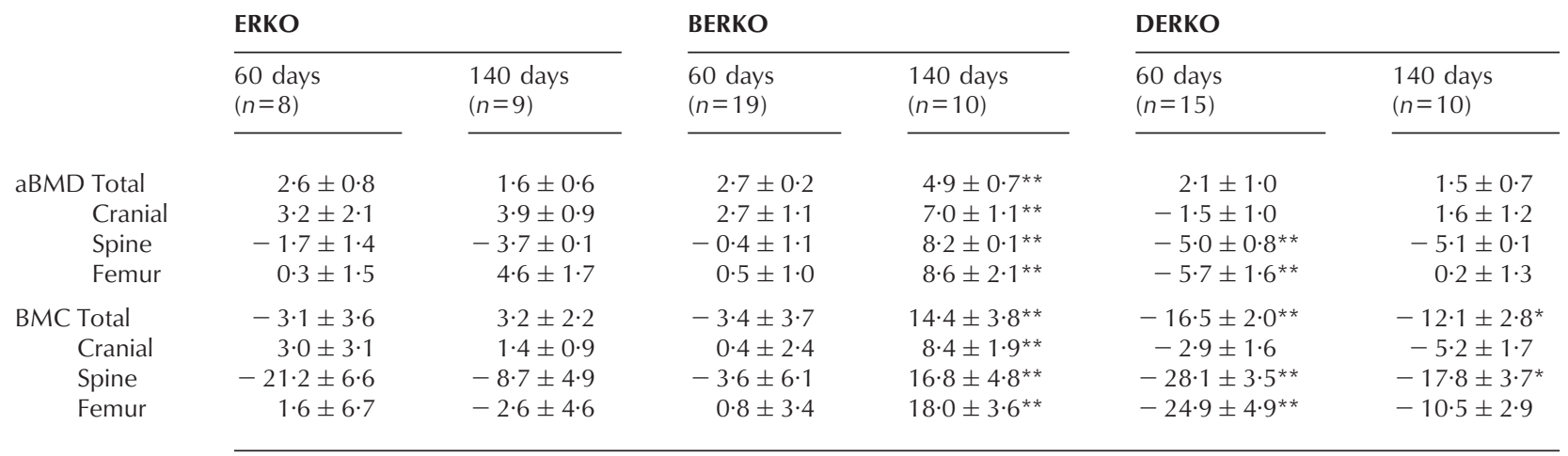

${ }^{*} P<0 \cdot 05,{ }^{*} P<0 \cdot 01$ versus WT, one-way ANOVA followed by Student-Newman-Keuls multiple range test.

was unchanged in all genotypes, while serum levels of c-telopeptide were increased in ERKO mice (54\%) compared with WT mice (Table 3).

\section{Discussion}

Estrogen exerts a variety of important physiological effects including regulation of longitudinal bone growth, body composition and trabecular bone mineral density. The ER specificity for these effects was in the present study characterized in female mice.

Estrogen is of importance for the regulation of fat mass in mice. Ovariectomy increases while substitution with estrogen inhibits weight gain in mice (Ornoy et al. 1994). Furthermore, aromatase deficiency results in obesity (Fisher et al. 1998). Increased adipose tissue has recently been described in ER $\alpha$-inactivated female mice (Heine et al. 2000). We have in the present study demonstrated that female ERKO and DERKO, but not BERKO, mice have increased fat content associated with increased serum levels of leptin. We cannot say if the increased body weight in ERKO and DERKO only is dependent on this increase in fat mass, as the muscle mass was not measured. However, our DXA data clearly demonstrates that the proportion of body fat is increased in female mice lacking
ER $\alpha$. Thus, endogenous estrogens decrease the fat content in female mice via $\operatorname{ER} \alpha$ and not $\operatorname{ER} \beta$. Similarly, we have recently described that $\operatorname{ER} \alpha$ but not $\operatorname{ER} \beta$ is of importance for the regulation of fat mass in male mice as well (Ohlsson et al. 2000).

We have previously shown that female ERKO mice have decreased femur length, and that this decrease is associated with a decrease in serum levels of IGF-I (Vidal et al. 1999b). These results in female ERKO mice were confirmed in the present study. Furthermore, ER $\beta$ inactivated mice displayed, both in the present study and in a previous study, an increased length of femur, which in the present study was shown to be associated with an increase of serum levels of IGF-I (Windahl et al. 1999). Interestingly, the length of femur and serum levels of IGF-I were, in female DERKO mice, intermediate between ERKO and BERKO mice. A fact supporting the notion that the GH-IGF-I axis might be involved in the estrogenic regulation of appendicular bone growth is that the serum IGF-I levels were strongly correlated to the femur length in the mice with ER inactivation. These data clearly demonstrate that $\operatorname{ER} \alpha$ and $\operatorname{ER} \beta$ have opposing effects regarding the effect on appendicular growth in female mice. We propose that $\operatorname{ER} \alpha$ promotes, while $\operatorname{ER} \beta$ represses, longitudinal bone growth in female mice. These findings are in line with the notion that $\operatorname{ER} \beta$ sometimes

Table 3 Serum parameters in 140-day-old female mice. Values are given as means \pm S.E.M.s (WT $n=4-16$, ERKO $n=3-14$, BERKO $n=4-17$, DERKO $n=4-16$ )

\begin{tabular}{|c|c|c|c|c|}
\hline & WT & ERKO & BERKO & DERKO \\
\hline $17 \beta$-Estradiol $(\mathrm{pmol} / \mathrm{l})$ & $32 \cdot 9 \pm 1 \cdot 1$ & $213 \cdot 7 \pm 12 \cdot 8^{\star *}$ & $36 \cdot 1 \pm 0 \cdot 7$ & $115 \cdot 5 \pm 5 \cdot 5^{* *}$ \\
\hline Testosterone $(\mathrm{ng} / \mathrm{ml})$ & ND & $1 \cdot 73 \pm 0 \cdot 12^{* *}$ & ND & $0 \cdot 19 \pm 0.05^{*}$ \\
\hline Osteocalcin (ng/ml) & $261 \pm 23$ & $178 \pm 27^{*}$ & $141 \pm 21^{* *}$ & $151 \pm 22^{* *}$ \\
\hline TRAP $5 b(\mathrm{U} / \mathrm{l})$ & $24 \cdot 4 \pm 1 \cdot 2$ & $20 \cdot 7 \pm 1 \cdot 9$ & $23 \cdot 2 \pm 2 \cdot 1$ & $23 \cdot 1 \pm 2 \cdot 0$ \\
\hline c-telopeptide (ng/ml) & $10 \cdot 8 \pm 1 \cdot 1$ & $16 \cdot 6 \pm 1 \cdot 3^{* *}$ & $9 \cdot 0 \pm 0 \cdot 6$ & $9 \cdot 7 \pm 1 \cdot 6$ \\
\hline
\end{tabular}

${ }^{*} P<0 \cdot 05,{ }^{*} P<0 \cdot 01$ versus $\mathrm{WT}, \mathrm{ND}=$ not detectable. One-way ANOVA followed by Student-Newman-Keuls multiple range test. 
acts as a repressor of ER $\alpha$-mediated effects, and is also supported by our recent study, demonstrating that $\operatorname{ER} \beta$ is a negative modulator of ER $\alpha$ activity in the immature uterus (Weihua et al. 2000). Furthermore, ER $\alpha$ and ER $\beta$ have previously been shown to exert opposing effects in vitro where $\mathrm{ER} \alpha$ promotes, while $\mathrm{ER} \beta$ inhibits transcription when complexed with $17 \beta$-estradiol at an AP-1 element (Paech et al. 1997). The estrogenic regulation of appendicular growth is somewhat different in males compared with females. In ERKO males the growth is repressed, resulting in shorter long bones, comparable with females. However, no effect is seen in BERKO males. Male DERKO mice follow the same growth pattern as male ERKO mice, in contrast to the intermediate growth seen in female DERKO mice. Thus, ER $\beta$ represses longitudinal bone growth in female mice, while it has no function in the regulation of longitudinal bone growth in male mice.

The trabecular BMD was increased in female ERKO mice. The mechanism behind this increase is unclear but one might speculate that the strongly elevated levels of testosterone in female ERKO mice might result in an increased activation of the androgen receptor. An alternative explanation is that the dramatically increased levels of $17 \beta$-estradiol seen in ERKO mice may result in an elevated activation of ER $\beta$ - and/or of $E R \alpha / \beta$-independent pathways and thereby result in increased trabecular BMD. The increased trabecular BMD in ERKO mice was unexpectedly associated with decreased levels of osteocalcin and increased levels of c-telopeptide. In the present study the trabecular BMD was measured in vivo in anesthetized mice using pQCT. We have previously shown that this sort of measurement of trabecular BMD is very well correlated to measurement of the ratio of trabecular bone volume (BV) to total volume (TV) (BV/TV) by histomorphometry (Windahl et al. 2001). The mice included in the present study were later used for other purposes, making it technically impossible to perform histomorphometric analysis on excised bones. BERKO mice aged 140 days had increased trabecular BMD and this finding is in accordance with what we have recently reported in 1-year-old female BERKO mice (Windahl et al. 1999). This increased trabecular BMD in 140-day-old BERKO mice might be due to increased ER $\alpha$ expression in bone tissue (Windahl et al. 2001). Both the aBMD in femur and spine as well as the trabecular BMD in the proximal tibia were clearly decreased in 60-day-old female DERKO mice. The observed decrease in trabecular BMD is similar to the effect of ovariectomy and is in accordance with the recent description of trabecular osteopenia in female aromatase-deficient (ArKO) mice, which lack endogenous production of estrogen ( $\mathrm{Oz}$ et al. 2000). These data indicate that a partial functional redundancy exists between ER $\alpha$ and ER $\beta$ regarding the protective effects of estrogen on trabecular BMD in female mice at 60 days of age, representing a young adult stage. However, in females at 140 days of age, the trabecular BMD is no longer decreased in DERKO mice. One explanation may be compensatory mechanisms that do not begin to act until after 60 days of age. Levels of estrogen as well as testosterone are elevated in female DERKO mice at 140 days of age, and one may speculate that these elevated levels of sex steroids result in a normalization of the trabecular BMD in the female DERKO via an ER $\alpha / \beta$ independent mechanism including, for instance, activation of the androgen receptor. Thus, a complex regulation of the trabecular BMD, probably caused by a disturbed feedback regulation of estrogen and testosterone, was observed in adult female ER-inactivated mice.

In the present study at least three different mechanisms of action of estrogen regarding ER specificity were observed. The first was effects mediated by only one receptor, as seen regarding regulation of fat content, which was an ER $\alpha$-dependent effect. The second type was the interesting opposing effect between $\operatorname{ER} \alpha$ and $\operatorname{ER} \beta$ seen in the regulation of longitudinal bone growth. A partial functional redundancy was the third type of effect, seen in 60-day-old mice regarding trabecular BMD, where ER $\alpha$ and $\operatorname{ER} \beta$ could partly replace each other in the maintenance of a normal trabecular BMD. Thus, $\operatorname{ER} \alpha$ and $\operatorname{ER} \beta$ may have separate effects, opposing effects or redundant effects, depending on which parameter is studied.

\section{Acknowledgements}

This study was supported by the Swedish Medical Research Council, the Swedish Foundation for Strategic Research, Lundberg Foundation, the Swedish Medical Society, Novo Nordisk Foundation, the Swedish Association Against Rheumatic Disease, the Swedish Cancer Fund, Karo Bio AB, the Emil and Vera Cornell Foundation, Petrus and Augusta Hedlunds Foundation, the Torsten and Ragnar Söderbergs Foundation and Academy of Finland. Excellent technical assistance was provided by Maud Pettersson at the Department of Clinical Pharmacology and Anette Hansevi at the Department of Internal Medicine, University of Gothenburg, Sweden. We would also like to thank the SWEGENE Center for Bio-Imaging (CBI), and Gothenburg University for technical support regarding Image analysis.

\section{References}

Alatalo SL, Halleen JM, Hentunen TA, Monkkonen J \& Vaananen HK 2000 Rapid screening method for osteoclast differentiation in vitro that measures tartrate-resistant acid phosphatase $5 \mathrm{~b}$ activity secreted into the culture medium. Clinical Chemistry 46 1751-1754.

Andersson N, Lindberg M, Ohlsson C, Anderson K \& Ryberg B 2001 Repeated in vivo determinations of bone mineral density during parathyroid hormone treatment in ovariectomized mice. Journal of Endocrinology 170 529-537. 
Arts J, Kuiper GG, Janssen JM, Gustafsson JA, Lowik CW, Pols HA \& van Leeuwen JP 1997 Differential expression of estrogen receptors alpha and beta mRNA during differentiation of human osteoblast SV-HFO cells. Endocrinology 138 5067-5070.

Blum WF \& Breier BH 1994 Radioimmunoassays for IGFs and IGFBPs. Growth Regulation 4 (Suppl 1) 11-19.

Couse JF, Hewitt SC, Bunch DO, Sar M, Walker VR, Davis BJ \& Korach KS 1999 Postnatal sex reversal of the ovaries in mice lacking estrogen receptors alpha and beta. Science 286 2328-2331.

Das SK, Taylor JA, Korach KS, Paria BC, Dey SK \& Lubahn DB 1997 Estrogenic responses in estrogen receptor-alpha deficient mice reveal a distinct estrogen signaling pathway. PNAS 94 12786-12791.

Fisher CR, Graves KH, Parlow AF \& Simpson ER 1998 Characterization of mice deficient in aromatase (ArKO) because of targeted disruption of the cyp19 gene. PNAS 95 6965-6970.

Green S, Walter P, Greene G, Krust A, Goffin C, Jensen E, Scrace G, Waterfield M \& Chambon P 1986 Cloning of the human oestrogen receptor cDNA. Journal of Steroid Biochemistry 24 77-83.

Halleen J, Hentunen TA, Hellman J \& Vaananen HK 1996 Tartrate-resistant acid phosphatase from human bone: purification and development of an immunoassay. Journal of Bone and Mineral Research 11 1444-1452.

Heine PA, Taylor JA, Iwamoto GA, Lubahn DB \& Cooke PS 2000 Increased adipose tissue in male and female estrogen receptor-alpha knockout mice. PNAS 97 12729-12734.

Iafrati MD, Karas RH, Aronovitz M, Kim S, Sullivan TR Jr, Lubahn DB, O’Donnell TF Jr, Korach KS \& Mendelsohn ME 1997 Estrogen inhibits the vascular injury response in estrogen receptor alpha-deficient mice. Nature Medicine 3 545-548.

Karas RH, Hodgin JB, Kwoun M, Krege JH, Aronovitz M, Mackey W, Gustafsson J A, Korach KS, Smithies O \& Mendelsohn ME 1999 Estrogen inhibits the vascular injury response in estrogen receptor beta-deficient female mice. PNAS 96 15133-15136.

Krege JH, Hodgin JB, Couse JF, Enmark E, Warner M, Mahler JF, Sar M, Korach K S, Gustafsson JA \& Smithies O 1998 Generation and reproductive phenotypes of mice lacking estrogen receptor beta. PNAS 95 15677-15682.

Kuiper GG, Enmark E, Pelto-Huikko M, Nilsson S \& Gustafsson JA 1996 Cloning of a novel receptor expressed in rat prostate and ovary. PNAS 93 5925-5930.

Kusec V, Virdi AS, Prince R \& Triffitt JT 1998 Localization of estrogen receptor-alpha in human and rabbit skeletal tissues. Journal of Clinical Endocrinology and Metabolism 83 2421-2428.

Lim SK, Won YJ, Lee HC, Huh KB \& Park YS 1999 A PCR analysis of ERalpha and ERbeta mRNA abundance in rats and the effect of ovariectomy. Journal of Bone and Mineral Research 14 1189-1196.

Lubahn DB, Moyer JS, Golding TS, Couse JF, Korach KS \& Smithies O 1993 Alteration of reproductive function but not prenatal sexual development after insertional disruption of the mouse estrogen receptor gene. PNAS 90 11162-11166.

Nilsson LO, Boman A, Savendahl L, Grigelioniene G, Ohlsson C, Ritzen EM \& Wroblewski J 1999 Demonstration of estrogen receptor-beta immunoreactivity in human growth plate cartilage. Journal of Clinical Endocrinology and Metabolism 84 370-373.

Ohlsson C, Hellberg N, Parini P, Vidal O, Bohlooly M, Rudling M, Lindberg MK, Warner M, Angelin B \& Gustafsson JA 2000
Obesity and disturbed lipoprotein profile in estrogen receptor-alpha-deficient male mice. Biochemical and Biophysical Research Communications 278 640-645.

Onoe Y, Miyaura C, Ohta H, Nozawa S \& Suda T 1997 Expression of estrogen receptor beta in rat bone. Endocrinology 138 4509-4512.

Ornoy A, Giron S, Aner R, Goldstein M, Boyan BD \& Schwartz Z 1994 Gender dependent effects of testosterone and 17 beta-estradiol on bone growth and modelling in young mice. Bone and Mineral 24 $43-58$.

Oz OK, Zerwekh JE, Fisher C, Graves K, Nanu L, Millsaps R \& Simpson ER 2000 Bone has a sexually dimorphic response to aromatase deficiency. Journal of Bone and Mineral Research $\mathbf{1 5}$ 507-514.

Paech K, Webb P, Kuiper GG, Nilsson S, Gustafsson J, Kushner PJ \& Scanlan TS 1997 Differential ligand activation of estrogen receptors ERalpha and ERbeta at AP1 sites. Science 277 1508-1510.

Richman C, Baylink DJ, Lang K, Dony C \& Mohan S 1999 Recombinant human insulin-like growth factor-binding protein-5 stimulates bone formation parameters in vitro and in vivo. Endocrinology 140 4699-4705.

Shughrue PJ, Lubahn DB, Negro-Vilar A, Korach KS \& Merchenthaler I 1997 Responses in the brain of estrogen receptor alpha-disrupted mice. PNAS 94 11008-11012.

Srivastava AK, Bhattacharyya S, Castillo G, Miyakoshi N, Mohan S \& Baylink DJ 2000 Development and evaluation of C-telopeptide enzyme-linked immunoassay for measurement of bone resorption in mouse serum. Bone 27 529-533.

Vidal O, Kindblom LG \& Ohlsson C 1999a Expression and localization of estrogen receptor-beta in murine and human bone. Journal of Bone and Mineral Research 14 923-929.

Vidal O, Lindberg M, Savendahl L, Lubahn DB, Ritzen EM, Gustafsson JA \& Ohlsson C 1999b Disproportional body growth in female estrogen receptor-alpha- inactivated mice. Biochemical and Biophysical Research Communications 265 569-571.

Vidal O, Lindberg MK, Hollberg K, Baylink DJ, Andersson G, Lubahn DB, Mohan S, Gustafsson JA \& Ohlsson C 2000 Estrogen receptor specificity in the regulation of skeletal growth and maturation in male mice. PNAS 97 5474-5479.

Weihua Z, Saji S, Makinen S, Cheng G, Jensen EV, Warner M \& Gustafsson JA 2000 Estrogen receptor (ER) beta, a modulator of ERalpha in the uterus. PNAS 97 5936-5941.

Windahl SH, Vidal O, Andersson G, Gustafsson JA \& Ohlsson C 1999 Increased cortical bone mineral content but unchanged trabecular bone mineral density in female ERbeta(-/-) mice. Journal of Clinical Investigation 104 895-901.

Windahl SH, Norgard M, Kuiper GG, Gustafsson JA \& Andersson G 2000 Cellular distribution of estrogen receptor beta in neonatal rat bone. Bone 26 117-121.

Windahl SH, Hollberg K, Vidal NO, Gustafsson J, Ohlsson C \& Andersson G 2001 Female estrogen receptor-b -/- mice are partially protected against age-related trabecular bone loss. Journal of Bone and Mineral Research 16 1388-1398.

Received 4 April 2001

Accepted 24 July 2001 